\title{
Life-purpose orientations of today's university students of a multicultural region
}

\author{
Irina Cheremisova ${ }^{1,{ }^{*}}$ Elena Zakharova $^{2}$, and Ekaterina Nikulova ${ }^{3}$ \\ ${ }^{1}$ Academy of the FPS of Russia, Department of Psychology, Ryazan, Russia \\ ${ }^{2}$ Lomonosov Moscow State University, Department of Psychology, Moscow, Russia \\ ${ }^{3}$ Moscow Institute of Psychoanalysis, Department of Psychology of Education, Moscow, \\ Russia
}

\begin{abstract}
You The article presents an empirical study of the life-purpose orientations of third- and fourth-year students of various directions of undergraduate training: "Psychology", "Environmental sciences", "Economics", "Law" of the Volga Humanitarian Institute (branch) of Volgograd State University. The study used the Life-Purpose Orientations Test (LPO technique) of D.A. Leontiev as the main technique. The results of respondents in this sample correspond to the average level of indicators on all scales. In addition, students were offered the author's questionnaire "What is valuable to you?" An analysis of the answers led to the conclusion that spiritual values are a priority for almost all students and "Family" is the most significant value.
\end{abstract}

\section{Introduction}

Sharp and rapid changes in social, economic, cultural, political and social life affect the value orientations, life purposes of people, especially young ones. Many Russian scientists emphasise the particular importance of the stage of higher education for the formation of personality, the sensitivity of this period for the formation of value orientations, goals, purposes, personality orientations $[1,2,3,4,5]$.

An analysis of recent studies on the life-purpose orientations of today's young people has shown that scientists are interested in this problem. However, it can be stated that there are not enough of such studies and they are isolated, disconnected $[4,6,7,8,9]$.

The formation of life-purpose orientations for young people in a multicultural region is distinguished by particular complexity [1]. Young people belonging to different ethnic cultures observe different national traditions and follow different social and religious norms. In the context of globalisation, it is important to maintain the identity of each ethnic culture without prejudice to representatives of other nationalities and society as a whole. Therefore, it is important at the stage of higher education to help a young person to determine his/her life prospects and purposes, to form a clear and solid system of value orientations. For this, it is necessary to identify and analyse the features of life-purpose orientations of today's university students. This analysis provides us with an opportunity to

\footnotetext{
*Corresponding author: irinarusa@inbox.ru
} 
develop a program of psychological support aimed at optimising the axiological sphere of future specialists with higher education. In addition, this will allow to identify a group of young people whose life-purpose orientations are formed insufficiently or reflect negative manifestations of personality orientation.

\section{Materials and research methods}

On the basis of a theoretical analysis of studies of life-purpose orientations, we determined the concept developed by T. Sakharova as the main one [10]. This author defines the lifepurpose orientations of a person as conscious and generalised principles of a person's life, his/her life goals, the psychological way of experiencing life. This includes not only values, but also an assessment of one's own achievements, their correlation with their own personal criteria.

An educational space influences the life-purpose orientations of students. The volume and content of students' life-purpose orientations may change as a result of psychological and pedagogical influence [8].

Life values have a complex hierarchical structure, which is largely determined by the orientation of the individual to material or spiritual values. Value is the significance of material, spiritual and natural objects, phenomena $[1,2,3,5]$.

The purpose of the study is to identify and describe the features of life-purpose orientations of today's university students of a multicultural region. The study was conducted in the Volgograd region. Representatives of more than 140 nationalities currently live in the Volgograd Region.

The hypothesis of the study was the assumption that the life-purpose orientations of today's university students in a multicultural region can be multidirectional and polar. Material well-being and personal success will be the main orientations.

Third- and fourth-year students of various directions of undergraduate training took part in this research: "Psychology", "Environmental sciences", "Economics", "Law" of the Volga Humanitarian Institute (branch) of Volgograd State University, 50 participants (36 girls and 14 boys) in total. The average age of the subjects is 20 years.

To achieve this goal, we used two methods aimed at studying the life-purpose orientations among today's university student. We implemented the Life-Purpose Orientations Test (LPO technique) of D.A. Leontiev as the main technique [11]. This technique allows to access the "source" of the purpose of life, which a person can find either in the future (goal), or in the present (process) or past (result), or in all three components of life.

In addition, students were offered the author's questionnaire "What is valuable to you?"

The test subjects were offered a form on which there were 10 lines, numbered from 1 to 10. On the first line there was the number 1 , and the number 10 on the last one.

We have identified the following evaluation parameters:

1. Type of values.

- Spiritual values (orientations aimed at supreme human values, at harmony with oneself and the surrounding world. For example: "Travel", "Freedom", "Family").

- Material values (what can be bought, sold, and so on. For example: "Car", "Computer", "Money").

2. Level of detail in answers.

- One-word answers (For example: “Goal”, “Career”).

- Expanded or detailed answers (have an explanation, clarification. For example: "To experience vivid emotions and events from time to time", "To create something for other people").

3. Pole of the value (positive/negative). 
- Positive values (which benefit the subject, positively affect life. For example: "Love", "Hobby").

- Negative values (characterized by a harmful effect on a person's life, which prevent $\mathrm{him} /$ her from being fulfilled within the society. For example: "Alcohol", "Prostitutes").

4. Significance for the person.

- The beginning of the rating (values indicated on the 1 st and 2 nd place of the list).

- The End of the rating (values indicated on the penultimate and the last place of the list).

5. The focus of value.

- On oneself (For example: "Self-realisation", "Self-affirmation in society").

- On other people (For example: "Relationships with other people", "Health of relatives and friends", "To have recognition in society").

- On the process of life (For example: "to do what you love," "to develop spiritually").

- On the qualities of personality (For example: "Kindness and honesty", "Skill of judgement-free communication", "Persistence of spirit/character").

\section{Results and discussion}

Average values for subscales for the LPO test (by D.A. Leontiev): Goals in life (31.62), Locus of control - Life (31.4), Process of life (29.54), Productivity of life (26.22), Locus of control - me (21.16). The general indicator of the sense of purpose in life (103.04). The results of our study are very close to the results obtained separately for men and women in a sample of 200 people aged 18 to 29 years (according to D.A. Leonttev, 2000). These results correspond to the average level of indicators on all scales.

The results of our study show that three- and four-year students on average have good indicators, which means that they have sufficiently formed values and goals in life.

An analysis of answers to the questionnaire "What is valuable to you?" allowed us to determine which values are important for students.

An analysis of the responses according to the "Value Type" parameter showed that spiritual values prevail among $91.47 \%$ of subjects. They stated the following values: "Love", "Friends", "Freedom", "Honour", "Creative activity", "Beauty", "Self-fulfillment", "Loyalty", "My and my loved ones' health". Material values prevail in the answers of $8.53 \%$ of respondents: "Car", "Money", "House", "Alcohol", "Computer".

Let us present the results of the analysis of the responses for the parameter "Level of detail in answers." Most of the questionnaires (78\%) contained one-word answers: "Stability", "Education", "Work", "Health", "Career", "Self-development", “Travel", "Success", "Purpose", "Dream", "Music", "Religion". A significant part of the questionnaires (22\%) contained detailed answers: "Close people and their support", "To be satisfied with life", "Personal shelter (house, apartment)", "To experience vivid emotions and events from time to time", "Freedom of thought, without any limits of self-judgment", "Desire to preserve childlike innocence", "Taking care of someone and receiving it back", "To share your interests with loved ones", "Openness to other people's interests and troubles", "To be necessary to people". Such answers may indicate a greater interest in this issue, a higher level of reflection of respondents.

Let us present the results of the analysis of the answers according to the parameter "Pole of value". An analysis of the responses allows us to conclude that $96 \%$ of students have positive values: "To be necessary to people", "Achievements", "Creativity", "Benefit for the people", "To do good", "Hobbies", "Respect of others to me", "To be fit", "To be attractive", "To be a good friend". Only a small number of responses (4\%) reflected negative values: "Alcohol", "Prostitutes", "Smoking". We can assume that these responses were rather a manifestation of a negative attitude to the research procedure. 
An analysis of the responses according to the parameter "The focus of value" showed that "Focus on oneself" is reflected in most of the answers (85.2\%). The characteristics of the "Process of Life" were indicated by $30.39 \%$ of respondents as a value. A considerable share of responses included statements that reflected "Focus on other people" (23.77\%). Among the responses there also were personality traits that young people consider valuable (9.42\%).

An analysis of the responses to the questionnaire by the "Significance for the person" parameter allowed us to conclude that the most significant values for respondents are: "Family" (34\%), "Love" (12\%), "Friends" (10\%), "Success" (6\%) and "Health" (7\%). Such responses as "Work", "Study", "Spirituality", "Life", "Pleasure", "Money" were also found at the top of the rating in insignificant numbers. At the lowest positions of the rating, respondents indicated "Hobbies", "Money", "Work". In some questionnaires, "Pleasure", "Self-development", "Travel", "Success", "Family" were indicated at the lower positions of the rating.

An analysis of the answers revealed the most common values throughout the sample: "Family" (93\%), "Friends" (70\%), "Love" (54\%). "Health" (48\%), "Money" (45\%), "Career" (45\%), "Hobbies" (43\%). Thus, we can conclude that material values (For example: "Money") are found in respondents' answers quite often. However, the largest number of mentions have such values as "Family", "Friends", "Love", which can be attributed to spiritual values.

Among the values indicated by the respondents, the statistical mode is "Family" (Mo = 47), that is, the family as the main value is chosen by the largest number of young people.

A qualitative assessment of the strength of relationship between the different lifepurpose orientations of university students and the types of values they choose was conducted with the help of Spearman rank correlation coefficient. For a sample of 50 people $(\mathrm{N}=50)$, a high reliability of the relationship analysis result $(\mathrm{p}=0.01)$ is observed at coefficient values $r s \geq 0.35$, sufficient accuracy $(p=0.05)$ at $r s \geq 0.27$.

A significant correlation is observed only between the subscale "Goals in life" and "Spiritual values" ( $\mathrm{rs}=0.28)$, "Goals in life" and "Positive values" (rs =0.309), "Sense of purpose in life" and "Spiritual values" (rs =0,308). Young people who have higher indicators in the "Sense of purpose in life" parameter and clear and precise goals in life are oriented towards positive, spiritual values. We found no correlation on negative values since this criterion is not very pronounced in the subjects. The indicators of students focused on material values had a negative correlation with all subscales of life-purpose orientations. Young people focused on financial and material well-being feel dissatisfaction with their lives and negatively assess their past.

The correlation between the criteria "Process of life" and "Personality traits" ( $\mathrm{rs}=$ 0.272 ) is statistically significant. This may suggest that a young person who indicates certain personality traits as a value reflects on self-development, self-improvement and is convinced that he/she is able to take control of his/her life.

An analysis of the results of an empirical study led to the conclusion that spiritual values are the priority for young people of the presented sample. In almost all questionnaires, respondents indicated positive values. The most important value for young people in this sample is "Family". In general, it can be stated that this study does not contradict the main conclusions made in studies of the life-purpose orientations of today's young people in different regions of Russia.

In our research, we used the LPO test of D.A. Leontiev as the main technique [11]. An analysis of $\mathrm{PhD}$ dissertations on life-purpose orientations showed that other researchers also use this technique $[4,6,8,9,13,14,15]$. Average values for subscales for the LPO test (by D.A. Leontiev) correspond to the average level of indicators on all scales and do not contradict the results obtained by N.N. Machurova, O.Yu. Getmanova $[9,12]$. 
Analysis of the results of the study of the life values of university students allowed N.N. Machurova to conclude that the most significant values are "personal life", "love, friendship, friends", "aesthetic values" [12].

In the researches of E.V.Martynova[6], O.Yu.Getmanov[9]a, were revealed gender differences in the content of life-purpose orientations. In our study, we could not identify any statistically significant differences in the life-purpose orientations of girls and boys.

The E.V. Martynova's study of life-purpose orientations as a factor in the personal preparation of pedagogical university students for professional activities shows that there is a connection between the place of terminal values on the ranking ladder (the Rokeach Value Survey) and the level of Sense of purpose in life (D.A. Leontiev's test). E.V. Martynova concluded that the higher the sense of purpose in life, the more significant social values compared to pragmatic ones [6].

The total sample in the study of V.A. Semikov is represented by students of $1-5$ courses of Faculty of Humanities majoring in Psychology and Social Work and first- and secondyear students of Faculty of Physics and Technology. V.A. Semikov believes that Humanities students are more "value mature" compared to students of the Faculty of Physics and Technology [13].

According to the results of S.V. Shkilev's study on the life-purpose orientations of students of Social Psychology faculty and the Romance-Germanic philology faculty, there is a correlation between all the parameters of the life-purpose orientations and the parameters of the socio-psychological adaptation of students in the process of high school education [4].

The life-purpose strategies of psychology students with various personality orientations were analysed by D.V. Egorov [14]. Students were divided into three groups according to their personality orientation: "Focus on oneself", "focus on communication" and "focus on business".

A comparative analysis of the results of the study of the life-purpose orientations of students of the Pedagogical Institute and students of the Theological Seminary allowed us to reveal and characterise significant differences [15]. N.V. Mozdor argues that theological education influences the formation of consistent life-purpose orientations of the humanistic approach [15].

\section{Conclusion}

Thus, an analysis of the results of an empirical study of the peculiarities of the life-purpose orientations of today's university students of a multicultural region showed that the assumption that the life-purpose orientations of today's university students of a multicultural region can be multidirectional and polar with a predominance of orientations on material well-being and personal success has not been confirmed. In almost all questionnaires, respondents indicated positive values. Spiritual values for young people of a humanitarian university of a multicultural region are highly significant. The most significant and frequently mentioned value is "Family". The findings of an empirical study can serve as the basis for developing a program of psychological support for the optimisation of the axiological sphere of future specialists. Particular attention in this program should be given to young people who have their life-purpose orientations insufficiently formed or reflect negative manifestations of personality orientation.

\section{References}

1. I.V. Abakumova, P.N. Yermakov, Voprosy psikhologii. 3, 78-82 (2003) 
2. O.A. Karabanova, O.V. Almazova, G.V. Burmenskaya, S.V. Molchanov, T.Yu. Sadovnikova, E.I. Zakharova, A.G. Dolgikh, Europ. Proc. of Soc. and Behav. Scien, XLIII, 634-642 (2018)

3. E.E. Gavrina, G.I. Aksenova, I.A. Koval chuk, N.A. Tyugaeva, Psychol. scien. and educ. 23 (5), 67-76 (2018)

4. S.V. Shkilev, Smyslozhiznennye orientatsii kak faktor sotsial'no-psikhologicheskoi adaptatsii studentov $v$ protsesse obucheniya $v$ vuze (2006)

5. I.V. Cheremisova, Psychological Magazine 2, 115-124 (2016)

6. E.V. Martynova, Smyslozhiznennye orientatsii kak faktor lichnostnoi podgotovki studentov pedvuza k professional'noi deyatel'nosti (2002)

7. N.L. Bykova, Spetsifika smyslozhiznennykh orientatsii razlichnykh grupp uchashcheisya molodezhi v situatsii sub"ektivatsii zhiznennykh tselei (2002)

8. I.G. Bogacheva, Smyslozhiznennye orientatsii uchashchikhsya v razlichnykh obrazovatel'nykh sredakh (2010)

9. O.Yu. Getmanova, Psikhologicheskie determinanty smyslozhiznennykh orientatsii predstavitelei razlichnykh sotsial'nykh grupp (1999)

10. T.N. Sakharova, Procedia Social and behavioral sciences Elsevier BV_146, 302307 (2014)

11. D.A. Leontiev, Test smyslozhiznennykh orientatsii (SZhO) (2006)

12. N.N. Machurova, Psikhologiya i praktika. Ezhegod. Ros. Psikh. Ob-va. 4(1) (1998)

13. V.A. Semikov, Psikhologo-akmeologicheskie osobennosti razvitiya smyslozhiznennykh tsennostei studentov gumanitarnogo profilya (2009)

14. D.V. Egorov, Samorealizatsiya kak komponent smyslozhiznennykh strategii studentov-psikhologov raznoi lichnostnoi napravlennosti (2007)

15. N.V. Mozdor, Razvitie smyslozhiznennykh orientatsii u studentov v protsesse bogoslovskogo i svetskogo obrazovaniya: na primere pedagogicheskogo (2007) 